\title{
Students' Comprehension of Arabic and English Terminology in Islamic Finance: A Comparative Study
}

\section{Isnaini Harahap, Marliyah, Mhd. Syahnan, Waizul Qarni, Sahkholid Nasution, Chuzaimah Batubara, and Khairina Tambunan}

Universitas Islam Negeri Sumatera Utara (UIN SU), Medan, Indonesia

\section{Abstract}

The rapid growing of Islamic finance sector is characterized by the establishment of Islamic financial institutions as well as Islamic financial market worldwide. Indonesia also shows significant development in this sector, which can be observed through the founding of various Islamic banking and insurance companies. As a result, Indonesian students' interests in taking majors in Islamic Economics and Business are skyrocketing in the last decade. However, this phenomenon is not without any challenges since those students come from different educational backgrounds, either Islamic or public

Corresponding Author: Isnaini Harahap

isnainiharahap@uinsu.ac.id

Received: 1 July 2019

Accepted: 18 July 2019

Published: 31 July 2019

Publishing services provided by Knowledge

(c) Isnaini Harahap et al. This article is distributed under the terms of the Creative Commons Attribution License, which permits unrestricted use and redistribution provided that the original author and source are credited.

Selection and Peer-review unde the responsibility of the AICLL 2019 Conference Committee. high schools. Meanwhile, Islamic finance uses much terminology taken from Arabic and English languages. This means that students from public high schools may not be familiar with the terms from those two languages, particularly the Arabic-derived ones. Thus, this study aimed to investigate Islamic Economics and Business UIN SU students' comprehension of Arabic and English Terminology used in Islamic Finance. Employing a descriptive quantitative approach, this study used questionnaire as the instrument of data collection. The results reveal interesting findings indicating students' comprehension of Arabic terminology is significantly higher than that of English one. It can be concluded that students coming from either Islamic or public educational background have no significant differences in understanding Islamic financial terms derived from Arabic and English languages.

Keywords: Islamic finance, mudharabah, murabahah, hedging, invoice

\section{Introduction}

The development of Islamic economy in Indonesia is not only influenced by the presence of Islamic financial institutions, but also the increasing number of educational institutions that offer Islamic economic studies. This field of study was originally developed at the State Islamic University, and now it has been offered in many public universities, such as; the University of Indonesia, The University of Gadjah Mada, and the University of 
of educational institutions in the field of Islamic economics in which the program has been operating since 2003 .

The number of people interested in studying Islamic economics is increasing every year. Interestingly, most of the students taking Islamic economic-related majors were graduated from public senior high school (80\%) while the others graduated from Islamic boarding schools or Islamic senior high school (Madrasa). The dominance of students who came from public schools may result in some challenges in the teaching and learning process in Islamic economic programs. This is due to the fact that there are rigorous number of terms derived from foreign languages, particularly English and Arabic.

Related to students' academic background prior joining Islamic economics major, it is assumed that most students will not find much challenge understanding the terms derived from English language. It is because English is the global language mostly spoken by people of different countries (Fithriani, 2018). In addition, English is the only compulsory foreign language subject studied at Indonesian schools (Fithriani, 2017). On the contrary, although Arabic is one of the most popular foreign languages learnt by Indonesian people, it is only compulsory for students studying at Islamic schools. Thus, understanding Arabic-derived terms may be a great challenge for students coming from public senior high schools.

Arabic-derived terms such as; mudharabah, musyarakah, and murabaha are much used in publications about Islamic economics and in products offered by Islamic banks in Indonesia. Research indicates that these terms have not been well understood by the community so that it becomes one contributing factor for the low preference of the community towards Islamic finance. In addition to Arabic terms, Islamic banking also uses many foreign terms derived from English, such as; accounts, and virtual which are difficult to be understood by students who previously studied in Islamic based institution. Thus, this study was aimed to investigate Islamic economic students' level of comprehension of Arabic and English terminology. Furthermore, this study also tried to compare their comprehension of the terms derived from the two languages.

\section{Literature Review}

Islamic economics has grown rapidly over the past two decades and has become the world financial trend today. The development of Islamic finance is marked by the growing number of banks and non-bank financial institutions offering Islamic financial products, a variety of services and infrastructure that support the sharia finance, and 
the opening of Islamic finance study programs in various universities as well as the scientific publications related to Islamic finance. This development can also be observed in Indonesia as one of the top ten countries that are considered to have the largest Islamic financial country index (IFCI) in the world. Based on the data from Global Islamic Finance Report (2018), Indonesia was ranked seventh in 2017 and has moved one position up to capture sixth position in 2018 (look at Figure 1 for details).

IFCI SCORE OF THE COUNTRIES RANKED 10TH TO 1ST

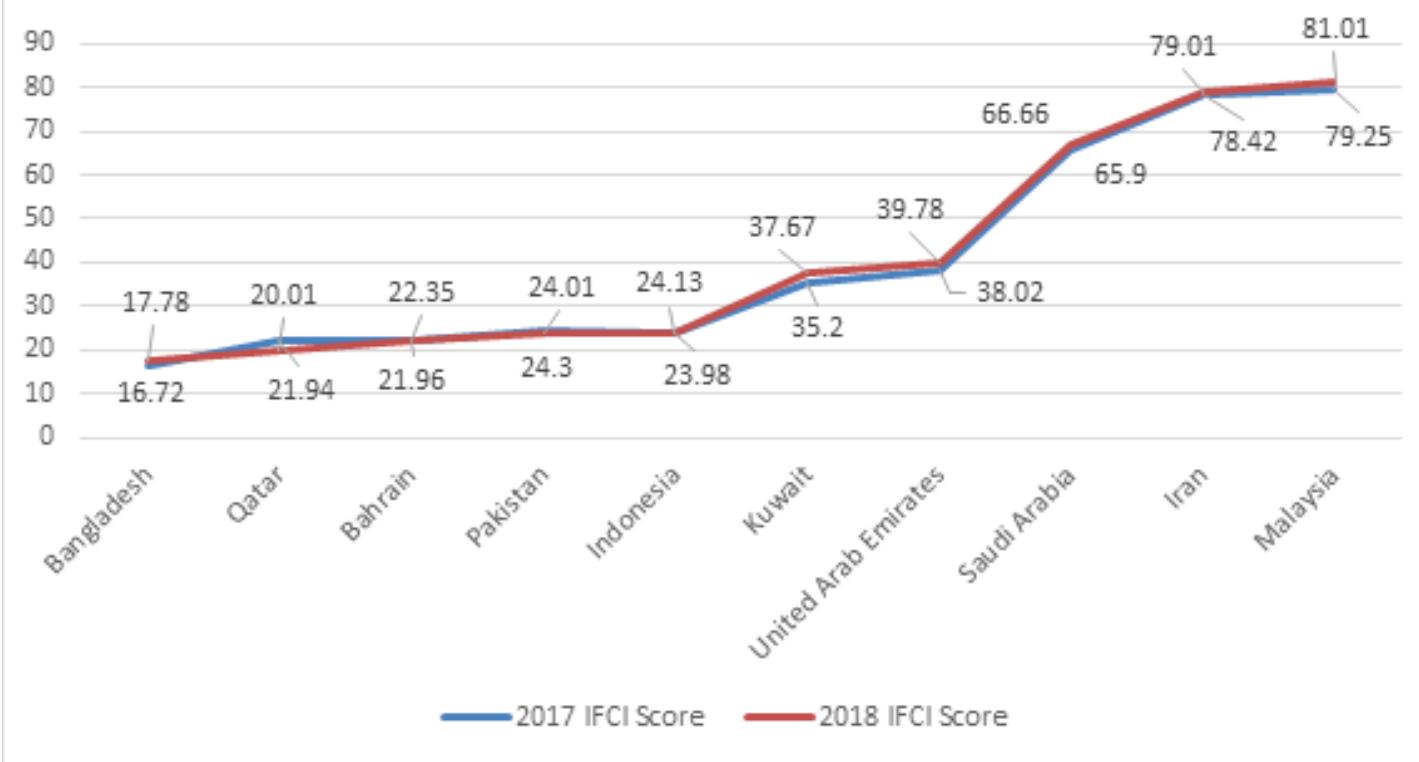

Figure 1: Top 10 Countries with the Highest IFCl Score in 2017 and 2018.

In terms of market share, Indonesia's sharia finance is around 8\%, however in terms of sharia financial products, some products have a market share above $5 \%$ as can be seen in table 1. The sharia products with a market share below $5 \%$ include corporate sukuk (sharia obligation which is similar to a bond in conventional finance), sharia insurance, and other non-Islamic financial industries 9the details can be seen in table 2).

TABLE 1: Market Share of Sharia Finance (Source: https://www.ojk.go.id).

Industry
Banking
NBFCs (Non-Bank Financial
Companies)
Capital Market
Total

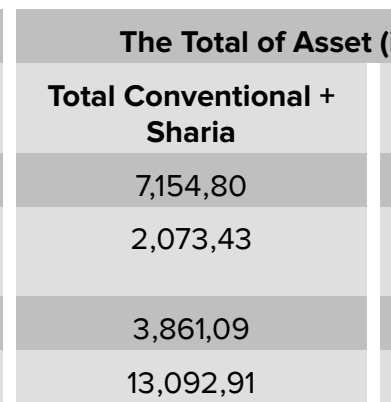

\begin{tabular}{c} 
Sharia \\
\hline 389,74 \\
99,15 \\
559,59 \\
$1,048,48$ \\
\hline
\end{tabular}

\begin{tabular}{c} 
Market Share (\%) \\
\hline 5,44 \\
\hline 4,78 \\
\hline 14,49 \\
\hline 8,01
\end{tabular}

The data in tables 1 and 2 suggest that Indonesia's sharia finance should be developed so that it can offset the growth of conventional finance and improve the financial 
industry successfully. In order to accelerate the growth of Islamic finance, especially when it is associated with the synergies between universities and Islamic financial institutions, various programs need to be carried out to solve the various obstacles to the development of Islamic finance, including:

\subsection{Supply and access to islamic financial products}

The development of Islamic finance in Indonesia still faces challenges in the form of limited supply of Islamic financial products and the limitation on Islamic financial products. Based on the table above, it can be seen that the three of the most developed Islamic financial products are the state's Islamic bonds, Islamic finance, and Islamic banking. Meanwhile, the most dominant financing scheme is murabahah followed by mudharabah and musyarakah (Harahap, 2016). The limited supply and access to sharia financial products is a challenge for universities that administer Islamic economics. It is needed to create a synergy with Islamic financial institutions to reconstruct new contracts so that they not rely on murabahah contracts (buying and selling).

\subsection{Limited human resources}

One factor that determines the performance and the improvement of sharia financial institutions is the quality of human resources and the supporting infrastructure. The quality of human resources needed by sharia financial institutions are the human resources who scientifically understand the concept of Islamic finance and psychologically possess great Islamic motivation. Unfortunately, of the 220 Islamic finance/ Sharia business that spread across the 160 universities, the human resources for sharia finance are not sufficient. In addition, beside of competency in which they need to compete with the graduates of non-Sharia economic programs. Relating to this, the universities should prepare the students with soft skills and hard skills related to Islamic economics.

\subsection{Public awareness towards islamic finance}

The increasing of public awareness towards sharia finance is an approach can be taken to develop Islamic finance. As the terms used in Islamic finance are in Arabic and English (Al-Saleem, 2014), the community thinks that Islamic finance is complicated and the public becomes unfamiliar with it. There are at least 142 terms of Islamic banking derived 
from Arabic, for examples; akad, mudharabah, ijarah, murabahah, and musyarakah (SS \& Giharto, 2007). Meanwhile the terms for sharia finance derived from English are 78 terms, of which 35 terms are absorbed and 23 terms are translated, such as; mobile banking, letter of credit, electronic payroll, hedging, virtual account, and hybrid contract (Ridwan, 2010). These words need to be translated into their equivalent words in Indonesia so that people can understand them. Several studies, such as; Ismahanto (Ismanto, 2018), Sardiana (Sardiana, 2016) and Megawaty (Megawaty, 2015) show that the people's awareness and understanding towards various sharia financial terms has influenced people's interest to be the customers of sharia banks. It is understood that the public wants to have the Indonesian terms for the marketing and disseminating Islamic bank products so that they can be understood easily. (Ghani, 2012)

TABLE 2: The Market Share of Sharia Finance Based on Industry Type (Source: OJK, 2018).

\begin{tabular}{l|c|}
\hline Type of Industry & $\begin{array}{c}\text { Market Share (per August } \\
\text { 2017) }\end{array}$ \\
\hline Sharia Banking & $5.44 \%$ \\
\hline Sharia Insurance & $4.94 \%$ \\
\hline Saria Financing & $8.11 \%$ \\
\hline Other NBFCs Sharia & $2.77 \%$ \\
\hline Corporate's Sukuk & $3.89 \%$ \\
\hline Sharia Mutual Fund & $5.07 \%$ \\
\hline The State's Islamic Bonds & $16.99 \%$
\end{tabular}

\section{Research Method}

This study used a quantitative descriptive approach. The respondents of this study were the second semester students of the Faculty of Islamic Business and Economics at the State Islamic University of North Sumatra who have never taken Muamalah figh and Islamic Banking courses. The number of respondents for this study was limited to 40 students. Questionnaires consisting of closed-ended and open-ended questions were used to measure students' understanding of the terms used sharia finance. The closed-ended part contains the terms commonly used in sharia financial transaction as seen in table 3. While the open-ended part contains questions to explore students understanding of those terms mentioned in part 1. Furthermore, students were also asked to explain some sharia financial terms in English and Arabic. The data collected through the questionnaires were then analyzed by using quantitative descriptive analysis. 
TABLE 3: Terminology in Sharia Financial Transaction Used in Questionnaire.

\begin{tabular}{l|l|l} 
Indonesian & Arabic & English \\
\hline Transaksi jual beli & Ba'i/Murabahah & Sale \\
\hline Pembiayaan & Tamwil & Financing \\
\hline Bagi hasil & Mudharabah & Profit sharing/Revenue sharing \\
\hline Sewa menyewa & ljarah & Leasing \\
\hline Gadai & Rahn & Mortgage \\
\hline Kerjasama & Musyarakah & Pathnership \\
\hline Keuntungan & Ribh & Profit \\
\hline Pinjaman lunak & Qardhul Hasan & Softloan \\
\hline Pembelian dengan pemesanan & Bai Salam & In front sale payment \\
\hline Bunga & Riba & Interest
\end{tabular}

\section{Discussion}

The students' understanding of the Islamic finance terminology is divided into two parts, namely; first, understanding of the terms commonly used in sharia financial products, and second, understanding of the contents used for sharia banking. In general, 50\% of the students who graduated from public educational institutions are able to mention the terms of Islamic financial products derived from Arabic, but unable to explain the meaning of these terms. For example, the ability to distinguish the terms 'bai' and 'murabahah' which have similar meaning of 'buying and selling'. However, the latter has a more specific meaning, that is 'buying and selling with the additional profit margins mentioned by the bank to the customer'. Meanwhile, students coming from Islamic educational Institutions have better understanding of these terms with $60 \%$ of them can explain those terms.

The second finding is that operationally, sharia financial terms derived from English, such as; clearing, virtual accounts, mobile banking, internet banking and RTGs (Realtime gross settlement), are not fully understood by the second semester students of Islamic Business and Economics Faculty who graduated from both public and Islamic educational institutions. Approximately about $60 \%$ of the students still do not understand the sharia financial terms, but they are familiar with several terms, such as; virtual accounts and mobile banking. Some of these terms are often heard, especially when paying the tuition.

Based on the findings above, in general, it can be said that the level of understanding of students who have not taken the sharia banking courses and muamalah fiqh on Islamic finance is still relatively low. Based on the OJK (Financial Services Authority), it can be considered as less illiterate. Though ideally, the students of Islamic business and 
economic Faculty should know the general terms of sharia finance even though they have not yet taken muamalah fiqh courses that specifically discuss various contracts and forms of financing commonly carried out by the sharia financial institutions from the classical era to the modern era. Likewise, Islamic banking courses that discuss sharia financial products and operations, including the financing mechanisms carried out between customers and the financial institutions should be understood well by the students.

An initial effort needs to be accomplished in order to get students closer to Islamic financial institutions since after all, understanding various Islamic finance is part of Islamic Finance literacy. The financial literacy of sharia finance is an ability to know and understand Islamic financial products and services based on sharia principles. Nationally, the level of Islamic finance literacy is still low. The National Survey on Financial Literacy and Inclusion conducted by the Financial Service Authority in 2016 resulted in a financial literacy index of $\mathbf{2 9 . 6 6}$ percent. Meanwhile, the Islamic financial literacy rate was only 8.11 percent (OJK (Otoritas Jasa Keuangan), 2013). This level is far below the literacy rate in Turkey which has reached 58\% (Er \& Mutlu, 2017), and in Malaysia at $66 \%$.

Students, as agents who are expected to drive the community literacy towards sharia finance should be well literate so that they can become partners in Islamic finance industry and the financial services authority in conducting education and socialization of Islamic finance. In the context of learning, students who study at the Faculty of Islamic business and economics should study about the Introduction of Islamic finance, both in the matriculation and during the orientation. In this way, it is expected that students' understanding towards the Islamic finance terms will be better.

\section{Conclusion}

Based on the findings above, it can be concluded that the students of Islamic business and economics faculty have understood the Islamic financial products, and they have better understanding about Islamic financial terms derived from Arabic. Meanwhile, in the operational aspects, they are more familiar with the terms derived from English. However, the level of students' understanding about these terms is still relatively low. Therefore, a kind of orientation and introduction toward Islamic finance should be given right after the students are accepted as the students of Islamic business and economics faculty. Finally, the findings indicate that students who graduated from general based 
institution or the Islamic based institution do not affect students' understanding toward the sharia financial terms. God knows best.

\section{References}

[1] Al-Saleem, K. O. (2014). The Translation of Financial Terms between English and Arabic, with Particular Reference to Islamic Banking. Salford, UK: School of Humanities, Languages and Social Sciences, University of Salford. Retrieved from http://usir.salford.ac.uk/id/eprint/30777/1/AISaleemThesis18.12.13.pdf

[2] Er, B., \& Mutlu, M. (2017). Financial Inclusion and Islamic Finance: A Survey of Islamic Financial Literacy Index. International Journal Of Islamic Economics And Finance Studies. International Journal of Islamic Economics and Finance Studies, 3(2). Retrieved from https://dergipark.org.tr/ijisef/issue/32886/365242

[3] Fithriani, R. (2017). Indonesian students' perceptions of written feedback in second language writing (Doctoral Dissertation). Retrieved from https://digitalrepository. unm.edu/educ_llss_etds/87/

[4] Fithriani, R. (2018) 'Discrimination behind Nest and Nnest Dichotomy in ELT Professionalism', in the 1st Annual International Conference on Language and Literature. KnE Social Sciences, pp. 741-755. doi: 10.18502/kss.v3i4.1982.

[5] Ghani, A. (2012). Konasi Masyarakat Terhadap Penggunaan Arabic Terms Dan Deskripsi Finance Scheme Dalam Pemasaran Produk Bank Syariah: Analisa Pada Masyarakat Kota Yogyakarta. JESI (Jurnal Ekonomi Syariah Indonesia), 2(2).

[6] Harahap, I. (2016). Analisis Dampak Penerapan Perbankan Syariah terhadap Sektor UMKM di Sumatera Utara. Universitas Islam Negeri Sumatera Utara. Retrieved from htp://repository.uinsu.ac.id/2399/

[7] Ismanto, K. (2018). Literasi Masyarakat dan Dampaknya terhadap Minat Menjadi Nasabah Bank Syariah. Human Falah, 5(1), 14-27.

[8] Megawaty. (2015). Analisis Pengetahuan Konsumen Mengenai Perbankan Syariah dan Pengaruhnya terhadap Keputusan Menjadi Nasabah pada PT. Bank Tabungan Negara Syariah (PERSERO) Cabang Makassar. Jurnal Minds: Manajemen Ide Dan Inspirasi, 2(2). Retrieved from http://journal.uin-alauddin.ac.id/index.php/minds/ article/viewFile/4626/4212

[9] OJK (Otoritas Jasa Keuangan). (2013). Survei Nasional Literasi dan Inklusi Keuangan 2016. Retrieved April 30, 2019, from https://www.ojk.go.id/id/beritadan-kegiatan/siaran-pers/Documents/Pages/Siaran-Pers-OJK-Indeks-Literasi-danInklusi-Keuangan-Meningkat/17.01.23TayanganPressconnett.compressed.pdf 
[10] Ridwan, M. (2010). Pengindonesian Istilah Perbankan Syariah pada Bank Syariah Mandiri dan Bank Muamalat Indonesia. Universitas Indonesia. Retrieved from http://lib.ui.ac.id/file?file=digital/20160832-RB01M428pPengindonesiaanistilahperbankan.pdf

[11] Sardiana, A. (2016). The Impact of Literacy to Shariah Financial Service Preferences. Etikonomi, 15(1). https://doi.org/https://doi.org/10.15408/etk.v15i1.3115

[12] SS, I., \& Giharto, M. H. (2007). Kamus Perbankan Syariah. Bandung: Penerbit Marja.

[13] Global Islamic Finance Report. (2018). Is/amic Finance Country Index 2018. Retreived from www.gifr.net/publications/gifr2018/ifci.pdf 